\title{
STRATIGRAPHIC ASPECTS OF THE ALTER DO CHÃO FORMATION IN THE NORTHERN REGION OF MANAUS, BASED ON GEOELECTRIC INFORMATION
}

\author{
João da Silva Carvalho ${ }^{1}$, Javier Tomasella², Shozo Shiraiwa ${ }^{3}$ and Rutenio Luiz Castro de Araujo ${ }^{4}$
}

\begin{abstract}
The geoelectrical survey was conducted in a portion of the northern edge of the Amazon Sedimentary Basin, between the kilometer 38 and the kilometer 96 of the BR-174 highway, dominated by sediments of the Alter do Chão Formation. We performed eight vertical electrical soundings (Schlumberger) and an electrical imaging section (dipole-dipole), using a portable resistivity (Syscal R2). The field data were processed using IPI2Win and RES2DINV softwares, resulting in the development of profiles and sections of electrical resistivity, which allowed the identification of lithologies and structures (faults) that affected this lithostratigraphic unit, as well as their contact relations with the rocks of the Manacapuru Formation, in this portion of land. In the Alter do Chão Formation, the highest resistivities are related to weathered materials of the superficial layers and sandstone in the deeper strata, which appear interspersed with thin layers of pelitic material. The results of electrical imaging performed in the portion of the northern boundary of Alter do Chão Formation, show the horizontal behavior of strata, highlights geological features (faults) and the south slope of its substrate, towards the center of the basin.
\end{abstract}

Keywords: geological features, lithology, electrical resistivity.

RESUMO. 0 levantamento geoelétrico foi realizado em uma porção da borda norte da Bacia Sedimentar do Amazonas, entre os quilômetros 38 e 96 da rodovia BR-174, onde predominam exposições sedimentares da Formação Alter do Chão. Foram realizadas oito sondagens elétricas verticais (Schlumberger) e uma seção de imageamento elétrico (Dipolo-dipolo), por meio de um resistivímetro portátil (Syscal R2). Os dados de campo foram processados por meio dos softwares IPI2Win e RES2DINV, que resultaram na elaboração de perfis e seções de resistividade elétrica, o que permitiu a identificação de litologias e estruturas (falhas) que afetaram as rochas dessa unidade litoestratigráfica, assim como suas relações de contato com as rochas da Formação Manacapuru, nessa porção territorial. No âmbito da Formação Alter do Chão, as resistividades mais elevadas estão relacionadas com materiais de alteração, nas camadas mais superficiais, e a estratos arenosos mais profundos, os quais aparecem intercalados com finas camadas de material pelítico. Os resultados do imageamento elétrico, realizado na porção do limite norte da Formação Alter do Chão, mostram o comportamento horizontal dos estratos, e destacam feições geológicas (falhas) e a declividade para sul do seu substrato, no sentido para o depocentro da bacia.

Palavras-chave: feições geológicas, litologias, resistividade elétrica.

\footnotetext{
${ }^{1}$ Departamento de Geociências - ICE, Universidade Federal do Amazonas (UFAM), Campus Universitário Arthur Virgílio Filho, Av. Rodrigo Octávio Jordão Ramos, 3000, Coroado I, 69080-005 Manaus, AM, Brazil. Programa de Pós-Graduação em Clima e Ambiente - CLIAMB/INPA/UEA, Av. André Araújo, 2936, Aleixo, 69060-001 Manaus, AM, Brazil. Phone: +55(92) 3305-2817/3305-2818; Fax: +55(92) 3305-2868 - E-mail: jscarvalho@ufam.edu.br

${ }^{2}$ Centro de Ciência do Sistema Terrestre, Instituto Nacional de Pesquisas Espaciais - MCT, Rodovia Presidente Dutra, km 39, Caixa Postal 01, 12630-000 Cachoeira Paulista, SP, Brazil. Phone: +55(12) 3186-8461; Fax: +55(12) 3101-2835 - E-mail: javier.tomasella@cptec.inpe.br

3 Instituto de Física, Universidade Federal de Mato Grosso, Av. Fernando Corrêa da Costa, s/n, 78060-900 Cuiabá, MT, Brazil. Phone: +55(65) 3615-8745; Fax: +55(65) 3615-8764 - E-mail: shozo@cpd.ufmt.br

${ }^{4}$ Departamento de Geociências - ICE, Universidade Federal do Amazonas (UFAM), Campus Universitário Arthur Virgílio Filho, Av. Rodrigo Octávio Jordão Ramos, 3000 , Coroado I, 69080-005 Manaus, AM, Brazil. Phone: +55(92) 3305-2817/3305-2818; Fax: +55(92) 3305-2868 - E-mail: ruie@ufam.edu.br
} 


\section{INTRODUCTION}

This study was conducted in a portion of the northern limit of the exposition of cretaceous sediments of the Alter do Chão Formation, along the federal highway BR-174, involving an area that goes from kilometer 38 up to near the Urubu river (on kilometer 96), as shown in Figure 1, and consisted of the execution of a horizontal electrical imaging section and various vertical electrical sounding. The main objective of this survey is to check the lithological behavior of the subsurface layers, as well as the identification of the lower limit of this unit, which rests discordantly on units of the Paleozoic sequence of the north edge of the Amazon Basin, represented by the Tapajós and Trombetas Groups (Caputo et al., 1972; Cunha et al., 1994; Cunha et al., 2007).

Locally, the Trombetas Group is represented by clastic sediments (sandstones fine to medium) and pelitic sediments (shales and laminated sillstones) of the Manacapuru Formation, deposited during periods of marine ingression/regression which occurred during the sineclise stage of the Amazon Basin evolution, and which is part of the great Ordovician-Devonian depositional sequence (Cunha et al., 1994, 2007).

The Alter do Chão Formation (Caputo et al., 1972) consists of fine to medium sandstone, clayey, unconsolidated and eventually conglomeratic, positioned discordantly on older units (Tapajós and Trombetas Groups) and covered by quaternary deposits. In general, the sediments of this stratigraphic unit form intercalary and discontinuous layers, which are superficially altered to a latossolic mantle, eventually with concretionary levels (Souza \& Nogueira, 2009).

These units are tectonically deformed, manifested by the occurrence of a system of normal and inverse flaws, which are locally responsible for the formation of waterfalls (like the waterfall ASFRAMA at kilometer 96 of the BR-174 highway) and additionally produce structures in the shape of grabens and horsts and promote relationships of contact with other units (Souza, 1974; Nogueira \& Sarges, 2001; Silva, 2005; Reis et al., 2006; Souza \& Nogueira, 2009).

\section{WORKING METHODS}

In this survey, eight vertical electrical sounding (VES) were performed, along the BR-174 highway and local roads, with use of Schlumberger configuration, plus a horizontal electric imaging with use of dipole-dipole configuration.

For the acquisition of the field data, it was used a digital resistivimeter (Syscal R2, manufactured by Iris Instruments) which allows simultaneous measurement of apparent resistivity and polarizability, besides allowing control of the efficiency in the contact resistance electrode/ground whenever necessary improved by the addition of salinated water. The location of the measurement points was determined by GPS and distances measured by tape.

\section{The vertical electrical sounding method (VES)}

The vertical electric sounding method aims to investigate the vertical distribution of apparent resistivity at depth, beneath a particular point on the topographic surface. The application of this technique, by configuring Schlumberger, consists of obtaining measurements of apparent resistivity from a linear distribution of electrodes on the surface topography, so that the electrodes of the current circuit ( $A$ and $B$ ) are positioned at the extremes and the electrode potential circuit ( $\mathrm{M}$ and $\mathrm{N}$ ) within the distribution, symmetrically positioned in relation to the common center (0) according to the order AMNB (Fig. 2). In accordance with this procedure, the greater the distance between the electrodes $A$ and $B\left(d_{A B}\right)$ is, the greater will be the density of current which will flow at greater depths, which allows to determine apparent resistivity values for different depths (Orellana, 1972; Dobrin \& Savit, 1988; Telford et al., 1990).

The apparent resistivity $\left(\rho_{a}\right)$ for this electrode configuration is determined by the formula:

$$
\rho_{a}=\pi \cdot a^{2} \cdot(\Delta V / I) / 2 . b
$$

where, $a=\mathrm{AB} / 2$ and $b=\mathrm{MN} / 2$.

Preliminarily, the depth of investigation $(z)$ is estimated to be around $1 / 4$ of the total opening between the electrodes of the current circuit, i.e. $z=\mathrm{AB} / 4$ (Telford et al., 1990), this ratio being dependent on the electrical conductivity contrasts between lithologies.

In this survey the vertical electrical soundings were made with electrodic openings (AB) from $2.0 \mathrm{~m}$ to $1.000 \mathrm{~m}$, defined by physical (topographic surface) and instrumental limitations, while the distances between the potential electrodes ( $\mathrm{M}$ and $\mathrm{N}$ ) ranged from $0.3 \mathrm{~m}$ to $10.0 \mathrm{~m}$. The VES were strategically placed along the BR-174 highway and local roads (extensions), as the following locations: (VES 1) on km 38 - Experimental Farm of Universidade Federal do Amazonas (UFAM); (VES 2) on km 41 (west bank), (VES 3) on km 50 (extension ZF2); (VES 4) on km 57 (farm); (VES 5) on km 63 (extension ZF3); (VES 6) on km 78 (extension), (VES 7) on km 94 and (VES 8) on km 96, as shown in Figure 1.

\section{The horizontal electrical imaging method (HEI)}

Research by horizontal electrical imaging (HEI) consists in obtaining measurements of apparent resistivity $\left(\rho_{a}\right)$ along a given 


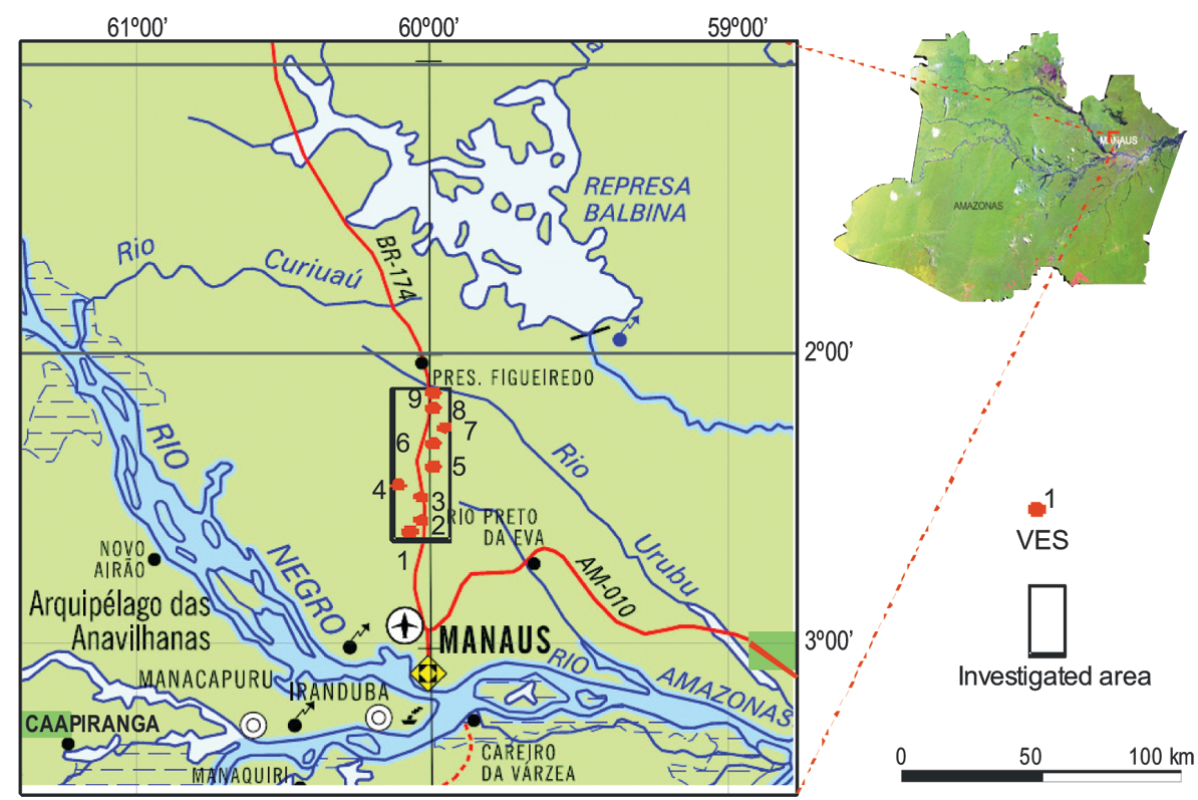

Figure 1 - Location map of the study area, identifying the points of investigation by VES and HEI (Source: IBGE).

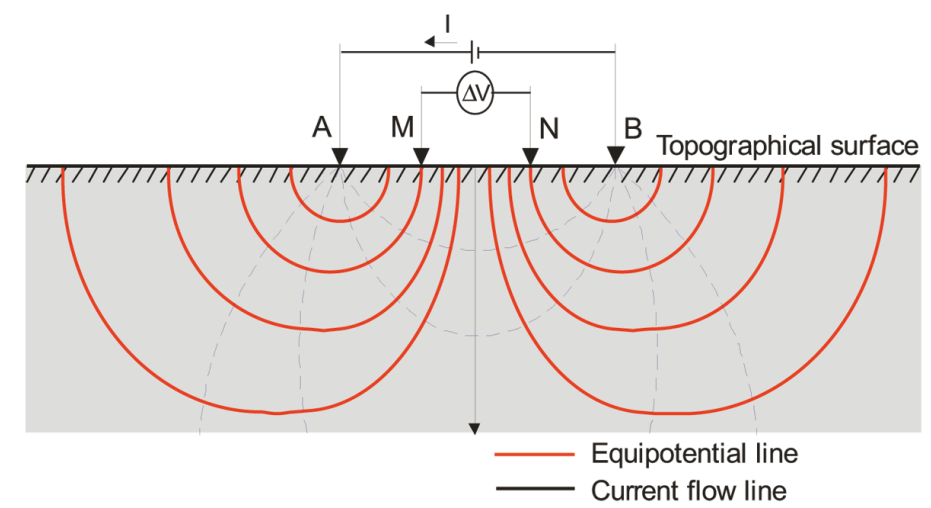

Figure 2 - Schematic representation of the technique of vertical electrical sounding by Schlumberger electrode configuration (Source: Braga, 2007).

alignment, through the lateral displacement of the electrode array positioned on the land surface (Braga, 2007). The execution of this survey, with use of dipole-dipole configuration, consists of the linear distribution of electrodes, forming two distinct dipolar circuits, one current ( $A$ and $B$ ) and a potential ( $M$ and $N$ ), in that order, keeping a constant distance between the electrodes of the dipoles, as schematized in Figure 3.

In practice, the research consists of, for each fixed position of the current dipole (AB), making as many $(n)$ measures for different positions of the potential dipole (MN), keeping regular distances $(n x)$ between the two dipoles, which allows the construction of an apparent resistivity section (formally called pseudosection of apparent resistivity).
The apparent resistivity $\left(\rho_{a}\right)$ in this case is determined by the formula:

$$
\rho_{a}=(\Delta V / I) \cdot \pi \cdot x n(n+1)(n+2)
$$

where:

$x=$ distance between the electrodes of the dipole $(m)$;

$n=$ multiplicative factor of $x$ which determines the distance between the dipoles and corresponds to the depth level of investigation ( $n=1,2,3,4, \ldots)$

As Braga (2007), the depth $(z)$ of investigation is determined as the order of half the distance between the centers of the dipoles $(z=R / 2$, where $R$ is the distance between the centers of the dipoles $\mathrm{AB}$ and $\mathrm{MN})$. 


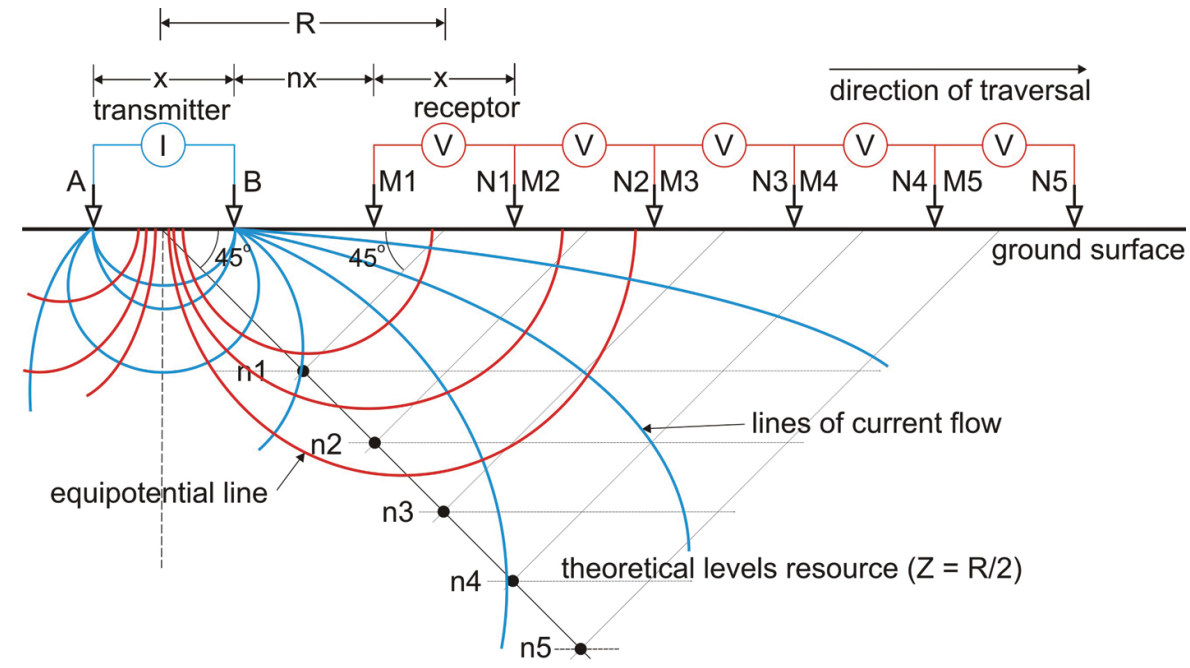

Figure 3 - Schematic representation of the dipole-dipole electrode configuration for HEl lifting (Source: Adapted from Braga, 2007).

For this survey, two sequential sections were conducted, with distance between electrodes of dipoles $(x)$ of $20 \mathrm{~m}$, totaling 840 meters in superficial length, with 5 levels of investigation $(n=5)$, aiming to reach depths (theoretically) ordered up to $60 \mathrm{~m}$.

\section{Data processing}

Data from vertical electrical soundings were processed through IPI2Win software (Bobachev et al., 2001), which allows, through iterative actions, determining the resistivity and thickness of each stratum, according to the configuration of the curve of apparent resistivity obtained in the field and supported by local geological information. In turn, the data from electrical imaging were processed in the RES2DINV program (methodology proposed by Loke \& Barker, 1996), which allows quick and efficient inversion of resistivity data based on the least squares method and smoothing that, theoretically, produces a model of 2-D subsurface, caused by the geometry of the electrode arrangement used (Gallas, 2000; Cutrim et al., 2004).

\section{RESULTS}

The results of the geoelectrical survey, by means of vertical electrical sounding and electrical imaging, within the limits of the investigated depth range, allowed to verify the lithostratigraphic behavior of the Alter do Chão Formation, as well as their relationships of contact with the Manacapuru Formation, in the portion of the boundary between these units.

The vertical electrical sounding, with an estimated depth range of up to $170 \mathrm{~m}$ were calibrated based on data from two wells drilled for groundwater extraction (Experimental Farm
UFAM, $150 \mathrm{~m}$ deep, and DELTA Construction, $110 \mathrm{~m}$ deep). The inversion process of the electrical imaging data were supported by information on exposures of rocks near the investigated site, including exposures of sandstones and shales of Manacapuru Formation (Trombetas Group).

\section{Results of vertical electrical sounding (VES)}

For evaluation purposes, the vertical electrical soundings were arranged along a segmented section and distributed from S-N, being VES 1 (UFAM's Experimental Farm, on $\mathrm{km} 38$ of the BR174 highway) further south, and VES 9 (ASFRAMA, on kilometer 94) to the north, as schematized in Figure 4, totaling a distance of about $60 \mathrm{~km}$. The coordinates (in $\mathrm{m}$ ) of the topographic surface in each VES, determined by surveying with GPS, are: VES 1 (98.8 m), VES 2 (75.2 m), VES 3 (121.2 m) VES 4 (128.1 m), VES 5 (130.2 m), VES 6 (131.8 m), VES 7 (98.2 m) and VES 8 $(71.7 \mathrm{~m})$, respectively.

In general, the results of vertical electrical soundings show a predominance of sandy materials to sandy clay, interspersed with clayey materials in layers with a maximum thickness of about $5 \mathrm{~m}$. In this study, they were identified models of four and five layers, where the top is usually the product of alteration (including lateritic soils) and others form intercalated layers of sand to clay. In this case, according to the classification of Orellana (1972), the VES 7 correspond to the model of three layers (type K), the VES 1, 3, 5, 6 and 8 correspond to the model of four layers, of the type HK $(\rho 1>\rho 2<\rho 3>\rho 4)$; the VES 2 and 4 fit the model of five layers, where the VES 2 HKH-type $(\rho 1>\rho 2<\rho 3>\rho 4<\rho 5)$ and VES 4 of the type KHK $(\rho 1<\rho 2>\rho 3<\rho 4>\rho 5)$. 


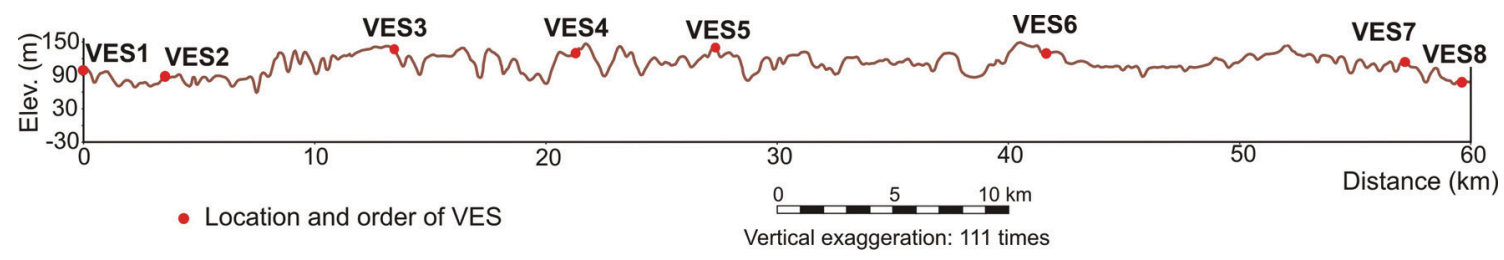

Figure 4 - Positioning of VES along a segmented topographic profile (SRTM) through all points of the soundings.

The result of the processing of VES 1, developed at UFAM's Experimental Farm (km 38 of BR-174 highway), identifies the configuration of a 4-layer system (Fig. 5), where the upper layer has resistivity of the order of $620 \Omega . \mathrm{m}$ and thickness of about $1 \mathrm{~m}$, representative of a clay material (compacted soil), passing to a layer with resistivity ranging between 150 and $706 \Omega$.m and total thickness of about $27 \mathrm{~m}$ (to a depth of about $28 \mathrm{~m}$ ) of clayey to clayey-sandy constitution. Under this, there is a layer with resistivity of about 2,700 $\Omega \mathrm{m}$ and thickness of about $72 \mathrm{~m}$ (depth of approximately $100 \mathrm{~m}$ ), sandy, with interleaving of clayey levels, and at the bottom, a layer eminently clayey, with resistivity of the order of $88 \Omega . m$.

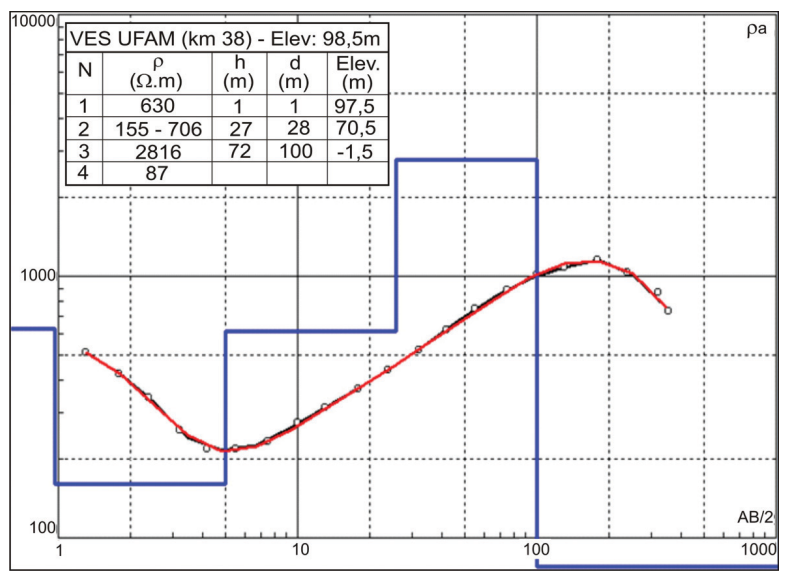

Figure 5 - Interpreted profile of the VES 1 (Experimental Farm UFAM - km 38 of BR-174 highway).

The VES 2, located at km 41 of BR-174 highway shows a system of five layers (Fig. 6), where the first (1 to 4 in the order of the model) shows resistivity ranging from $300 \Omega . m$ to $920 \Omega . m$ and total thickness of approximately $14 \mathrm{~m}$, referring to a sequence of clayey-sandy material, intercalated with sandy-clayey material, which is superimposed to a thick layer (over $120 \mathrm{~m}$ ), a sandy formation with resistivity on the order of 2,300 $\Omega . \mathrm{m}$.

The VES 3, held at $\mathrm{km} 2.6$ on the extension ZF2 ( $\mathrm{km} 50$ of BR-174 highway), shows a four layer model (Fig. 7), as follows: (1) layer with resistivity of the order of $1,600 \Omega . \mathrm{m}$, sandyclayey constitution, compressed, with about $0.5 \mathrm{~m}$ of thickness, (2) clayey-sandy layer, with resistivity ranging between 170 and
$370 \Omega$.m, with thickness on the order of $5 \mathrm{~m}$; (3) layer with resistivity of the order 2,600 $\Omega . m$, sandy, about $55 \mathrm{~m}$ thick; (4) sandy to sandy-clayey layer, with resistivity ranging between 637 and $960 \Omega . m$ and thickness of the order of $114 \mathrm{~m}$.

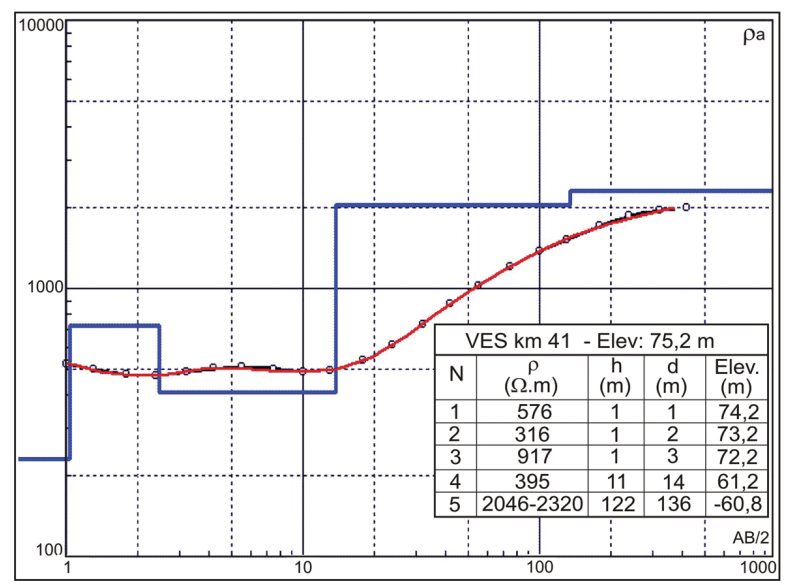

Figure 6 - Interpreted profile of the VES 2 (km 41 of BR-174 highway).

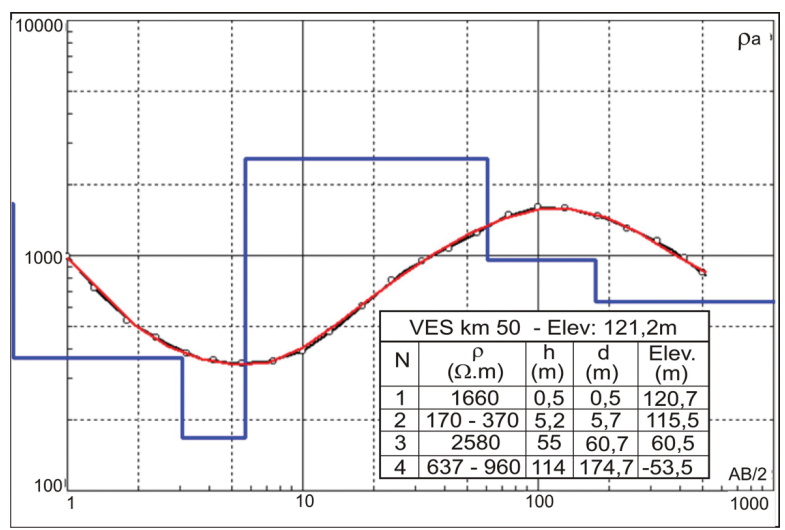

Figure 7 - Profile of the VES 3 (Extension ZF2 - km 50 of BR-174 highway).

The profile of the VES 4 (km 57 of BR-174 highway) shows the configuration of a system of five layers (Fig. 8), as follows: (1) Layer eminently clayey (resistivity of the order of $55 \Omega . m$ ) and thickness of $0.3 \mathrm{~m}$; (2) sand layer, with resistivity of the order of 3,640 $\Omega . \mathrm{m}$ and thickness of about $0.3 \mathrm{~m}$; (3) layer of low resistivity (on the order of $30 \Omega . m$ ), clayey, about $1.4 \mathrm{~m}$ thick; (4) layer with resistivity ranging between 1,270 and 2,560 $\Omega . m$, 
sandy-clayey to sandy formation, about $140 \mathrm{~m}$ thick, and (5) layer of low resistivity (of the order of $120 \Omega . \mathrm{m}$ ) and clayey composition.

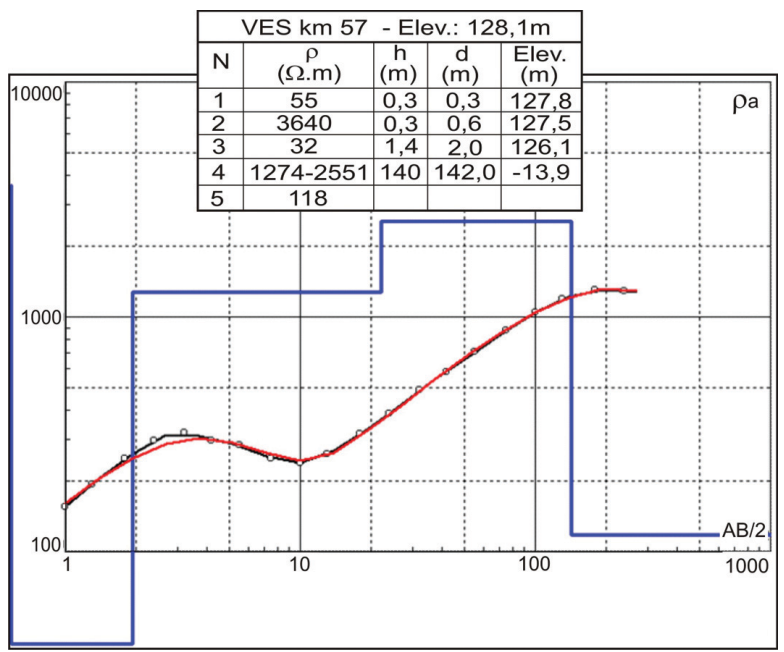

Figure 8 - Interpreted profile of the VES 4 (km 57 of BR-174 highway).

The VES 5, held at km 01 of the extension ZF3 ( $\mathrm{km} 63$ of BR-174 highway), is a four layer model (Fig. 9), being: (1) layer of clayey-sandy formation, with resistivity of the order of $583 \Omega$.m of $1.2 \mathrm{~m}$ thick; (2) clayey to clayey-sandy layer with moderate resistivity (ranging between 95 and $438 \Omega$.m) and a thickness of the order of $17 \mathrm{~m}$; (3) layer of higher resistivity (the order of 2,140 $\Omega . m$ ) of sandy nature, about $100 \mathrm{~m}$ thick, and (4) low resistivity layer (approximately $77 \Omega . m$ ), clayey formation.

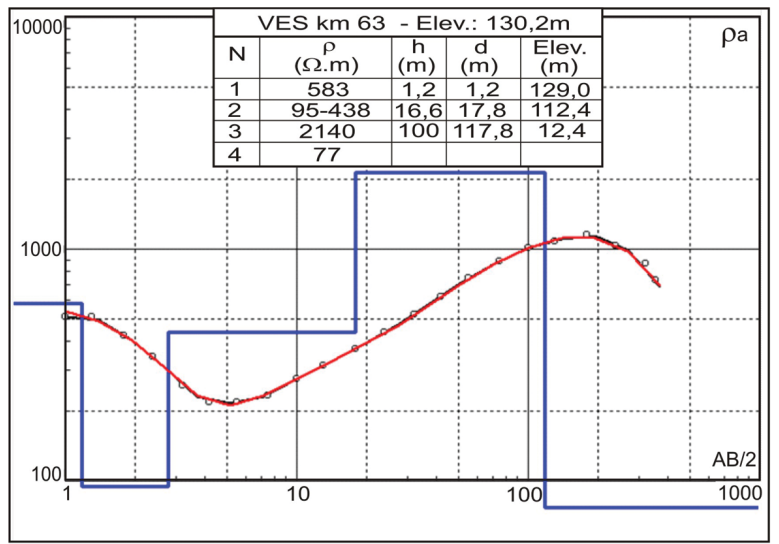

Figure 9 - Interpreted profile of the VES 5 (Extension ZF3 - km 63 of BR-174 highway).

The profile of VES 6, located at km 78 of the BR-174 highway, shows a four layer system (Fig. 10), with intercalations, being: (1) layer of soil (clayey-sandy), with resistivity of the order of $388 \Omega . m$ and estimated thickness of $1.3 \mathrm{~m}$, (2) clayey to clayey-sandy layer, with resistivity ranging between 221 and
$838 \Omega . \mathrm{m}$ and thickness of the order of $40 \mathrm{~m}$, (3) high resistivity layer (about 5,400 $\Omega . \mathrm{m}$ ), sandy, compact, with approximately $58 \mathrm{~m}$ of thickness, and (4) sandy layer, probably finer grain, with resistivity of the order of $3,830 \Omega$.m, with resistivity tended to decrease with increasing depth.

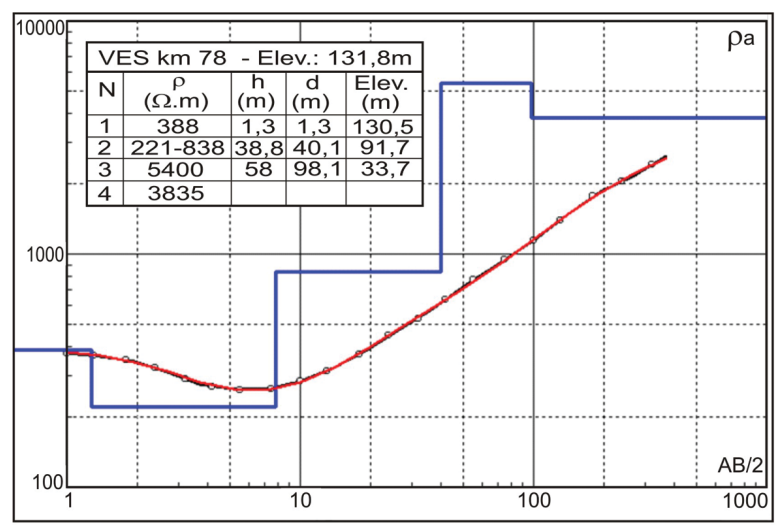

Figure 10 - Interpreted profile of the VES 6 (km 78 of BR-174 highway).

The VES 7 (west bank of the BR-174 highway - km 94) is a system of three main layers (Fig. 11), with intercalations, being: (1) layer of clayey-sandy constitution, with resistivity ranging from 310 to $926 \Omega . \mathrm{m}$ and total thickness of approximately $23.0 \mathrm{~m}$, (2) sand layer, with resistivity of the order of $5,460 \Omega . \mathrm{m}$ and thickness of about $40 \mathrm{~m}$ and (3) layer with a resistivity of about $192 \Omega$.m, eminently clayey.

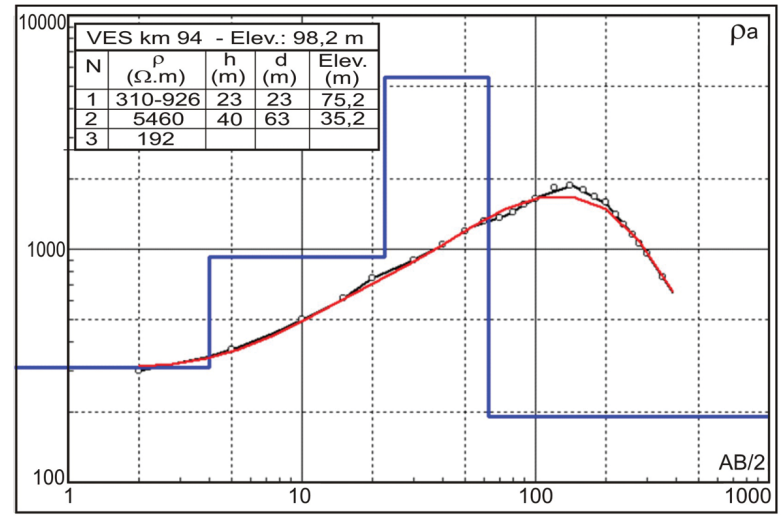

Figure 11 - Profile of the VES 7 (km 94 of BR-174 highway (east bank)

The VES 8, located at kilometer 96 of BR-174 highway (in front of the waterfall ASFRAMA) on sediments of the Manacapuru Formation, shows a four layer model (Fig. 12), with interbedded levels, being: (1) surface layer of sandy constitution, with high resistivity (of the order of 3,700 $\Omega . \mathrm{m}$ ) and thickness of approximately $1.0 \mathrm{~m}$; (2) layer resistivity of about 1,900 $\Omega . \mathrm{m}$, whether sandy to sandy clay with a thickness of about 4 meters; (3) high resistivity layer (ranging from 4,234 to $3,180 \Omega . m$ ) of 


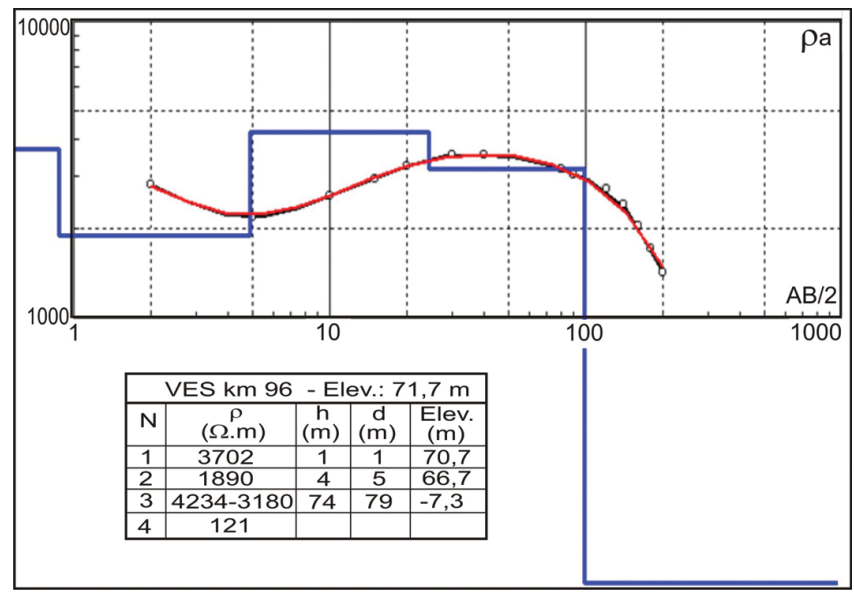

Figure 12 - Profile of the VES 8 ( $k$ 96 of BR-174 highway - ASFRAMA).

formation sand with a thickness of about $74 \mathrm{~m}$ and (4) low resistivity layer (120 $\Omega . \mathrm{m})$ of constitution clayey.

Figure 13 shows the stratigraphic correlation between the columns of VES, which is taken into account the different strata geoelectrical, compared to the geological information available on wells, and considering possible interference of geomorphological and geological features (geotectonic) along the trajectory of section.

The geoelectrical configuration of VES 3 ( $\mathrm{km} \mathrm{50),} \mathrm{highlight}$ the prevalence of moderate resistivity materials to greater depths, characteristic of sandy clay sediments, intercalated with clayey levels. This point is located at the headwaters of the Cuieiras and Preto da Eva rivers and the Tarumã Açu and Tarumã Mirim streams, which is a feature of high relief, showing drainage pattern with eccentric radial configuration.

From the results of the VES 6, located at kilometer 78 of BR-174 highway, it was noticed the occurrence of layers of high resistivity, representing sandy materials, compact, with different behavior from those of Alter do Chão Formation, and meet affected by tectonic processes.

The VES 8, located at $\mathrm{km} \mathrm{96}$, is in the land of the Manacapuru Formation (Trombetas Group), where higher resistivity materials dominated, related to the high degree of grittiness still occurring, at greater depths, materials with pelitic features, like the shales that outcrop in the $\mathrm{km} 98$ of this highway.

\section{Results of horizontal electrical imaging (HEI)}

The results of the electrical imaging performed at kilometer 94 of BR-174 highway, near the surface boundary of the cretaceous sediments of the Alter do Chão Formation with paleozoic rocks of the Trombetas Group, allowed the construction of a section of electrical resistivity with inverted model (processed in RES2DINV software), with use of dipole-dipole configuration ( $a=20 \mathrm{~m}$ ) and research on 5 levels deep.

Figure 14 shows the pseudo-section of apparent resistivity obtained in the field (top), the pseudo-section of apparent resistivity calculated by the model (middle) and inverted model (bottom), obtained through 3 iterations (with error estimated in about $15 \%$ ), resulting from the processing of data from a section of electrical imaging performed at the northern limit of exhibitions of the Alter do Chão Formation, which makes superficial contact with Manacapuru Formation's sediments. In this section, there is a stratified sequence, with increasing resistivity with depth, highlighting a high resistive layer, which occurs at about $25 \mathrm{~m}$ deep, which tapers towards the boundary of the Alter do Chão unit. This behavior is consistent with the configuration of the stratigraphic distribution model proposed by Petrobras and CPRM, and corroborates the data obtained in the vertical electrical sounding. It was also noticed the presence of discontinuities in the sequence, caused by the existence of tectonic features (faults), which promoted the individualization of blocks of sandstones of the Manacapuru Formation.

\section{CONCLUSIONS}

The results of this survey allowed identifying geoelectric features perfectly correlated with lithologies commonly found in this portion of the Amazon basin, as observed in wells with available lithostratigraphic information, including data from Manaus Stratigraphic Well - PETROBRAS (Aguiar et al., 2002), which still is the best stratigraphic reference available for this region. The calibration of electrical resistivity data was based on information 


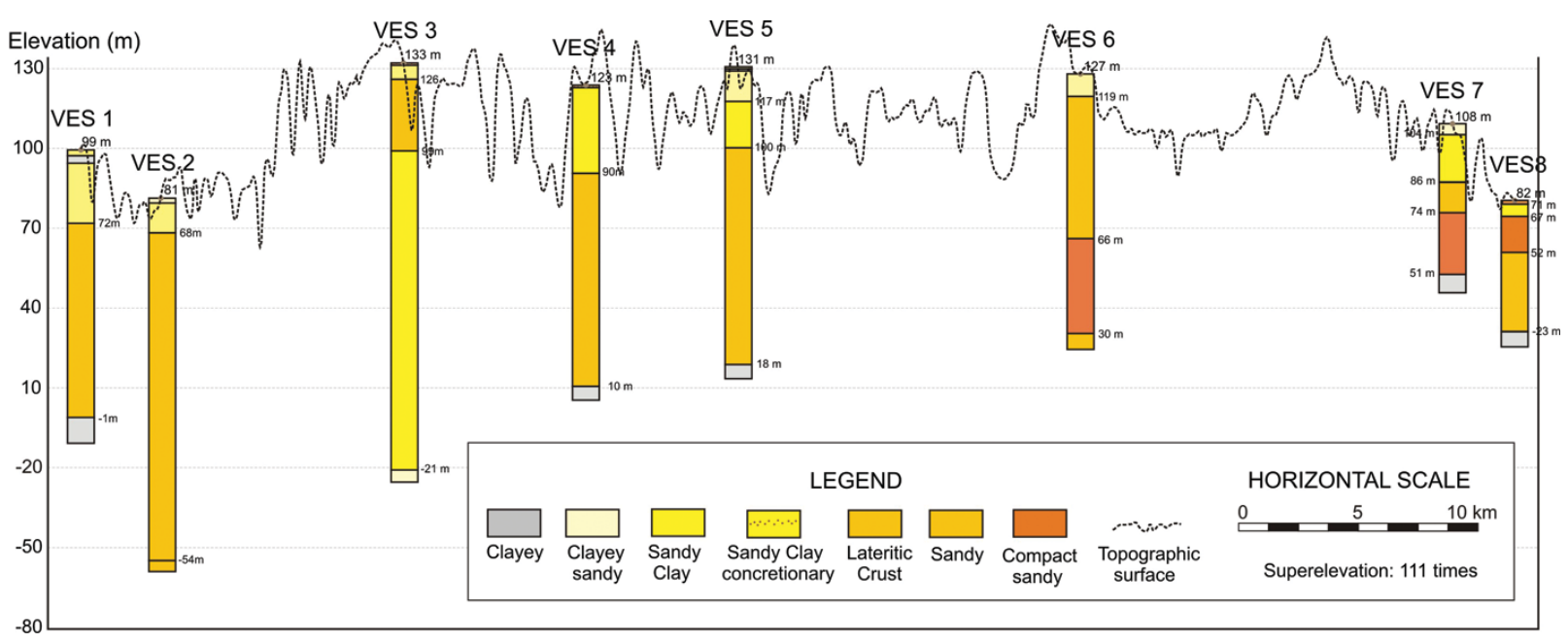

Figure 13 - Stratigraphic correlation resulting from the interpretation of the VES.
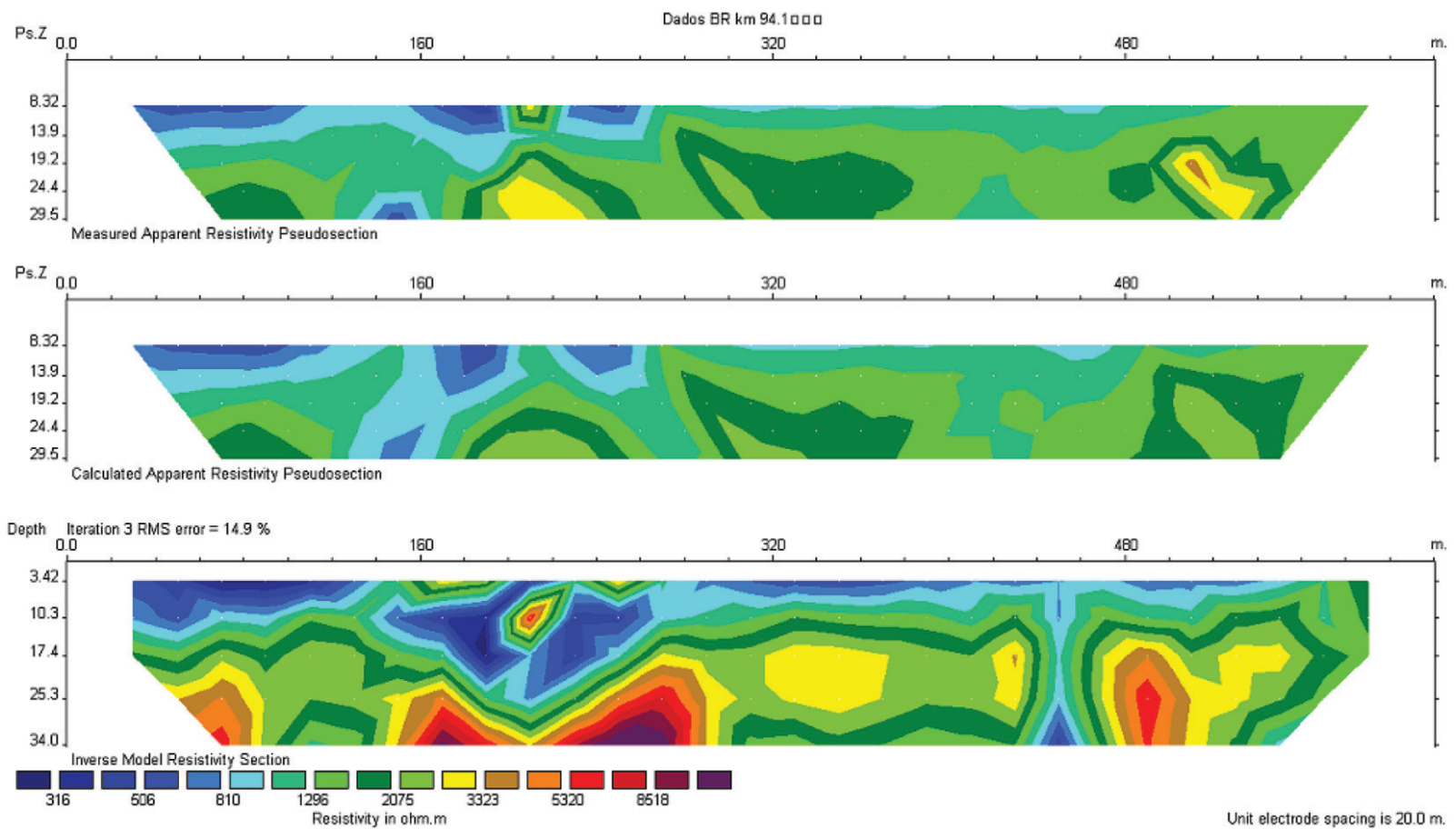

Figure 14 - Pseudo-section of electrical resistivity of a portion of the northern boundary of the Alter do Chão Formation (km 94 of BR-174 highway), with displacement from S-N.

from the wells UFAM Experimental Farm and DELTA Construction, supported by lithological exhibitions along the investigated stretch, and allowed a better evaluation of results regarding the spatial distribution of geoelectric and lithostratigraphic units, as well as their sizing parameters, especially thickness and depth.

Thus, the high resistivity values obtained for shallower levels in the field of Alter do Chão Formation, are due mainly to the presence of weathering products (latosols and lateritic concre- tions), deposits of sandy material (sand) or compressed soil as a result of human intervention. In the northern portion (VES 8), in the field of Manacapuru Formation (Trombetas Group), these high values are related to the occurrence of sandy material from this unit, latosols or ferruginous concretions, or the levels of thick texture (conglomeratic sandy), as observed locally. Moreover, the high resistivity anomalies observed at depths (VES 6 and 7) are related to the occurrence of sandy rocks (sandstones) 
of the Manacapuru Formation (Trombetas Group), which constitute the substrate of the ASFRAMA waterfall, at $\mathrm{km} 96$ of BR-174 highway.

In general context, the VES show interleaving of pelitic sediments (clayey) within the sand layers, as well as their lateral discontinuities, related to the processes of formation of these products, as well as to vertical displacements produced by faultings.

The geoelectric section held at $\mathrm{km}$ 94, the boundary zone of Alter do Chão Formation with Manacapuru Formation (Trombetas Group), shows the relationships of contact between these units, as well as the inclination to southern substrate of the Alter do Chão Formation and subhorizontal bedding of its strata. It was noticed, also, the presence of faults, which individualize blocks, possibly with subvertical gaps. Likewise, the presence of pelitic rocks below the sandy package can signal the presence of contact with other oldest stratigraphic units from the basin, just as occurred in VES 1 and 2 (possibly shales of Nova Olinda Formation) and VES 7 and 8 (shales of the Manacapuru Formation).

The predominance of clayey-sandy to sandy land materials in the field of Alter do Chão Formation has great hydrogeological importance, since it is a constituent part of the aquifer system of the same name. However, the discontinuities and lateral displacements produced by faults may influence greatly on the storage and flow of the water inside the materials. Moreover, because it is a free aquifer type system, the preservation of this territorial portion has great environmental importance, not only to maintenance of normality in the process of reloading it, but also for the preservation of the sanitarian characteristics of this important and strategic source of water of good chemical quality. Therefore, it is necessary to develop further studies on the stratigraphic and structural aspects of these plots, with improvement of direct information (geological mapping of surface and wells' data) and indirect information (geophysical), allowing establishing a more refined hydrodynamic model, which considers not just the hydrogeological parameters, as well as the kinematic of tectonic processes affecting such land.

\section{ACKNOWLEDGMENTS}

This work was sponsored by CNPq (process no. 47.5984/20099), with the support from the Instituto Nacional de Pesquisas da Amazônia (INPA) and Universidade do Estado do Amazonas (UEA), through the Post-Graduation Program on Climate and Enviroment, as well as the Universidade Federal do Amazonas (UFAM). We are also grateful to Geophysics 1 (Geofísica I) stu- dents, from UFAM's Geology Course (Class 2010/2), which assisted in the phase of geophysical data acquisition, and Dr. Alteredo Cutrim, from the Universidade Federal do Mato Grosso (UFMT), for suggestions and support in collecting geophysical data.

\section{REFERENCES}

AGUIAR CJB, HORBE MA, ROSA FILHO SF, LOPES ES, MOURA UF, ANDRADE NM \& DIÓGENES HS. 2002. Carta hidrogeológica da cidade de Manaus. CPRM-AM Manaus, Relatório Interno, 1-4.

BOBACHEV AA, MODIN IN \& SHEVNIN VA. 2001. IPI2Win, 1D interpretation os VES profile, Versão 2.0, Geoscam/Moscow State University, Moscow. Available on: <http://geophys.geol.msu.ru/ipi2win.htm>. Access on: 10.10.2011.

BRAGA ACO. 2007. Métodos Geoelétricos Aplicados - Módulo Hidrogeologia. UNESP, Rio Claro (SP). Available on:

$<$ http://www.rc.unesp.br/igce/aplicada/DIDATICOS/BRAGA/Geofisica/ Geoeletricos-V3.pdf $>$. Access on 20.10.2010.

CAPUTO MV, RODRIGUES R \& VASCONCELOS DNN. 1972. Nomenclatura estratigráfica da Bacia do Amazonas - histórico e atualização. 3 , Belém (PA). In: Congresso Brasileiro de Geologia, SBG, p. 36-46.

CUNHA PRC, GONZAGA FG, COUTINHO LFC \& FEIJÓ FJ. 1994. Bacia do Amazonas. Bol. Geoc., da Petrobras, Rio de Janeiro (RJ), 8(1): 47-55.

CUNHA PRC, MELO JHG \& SILVA OB. 2007. Bacia do Amazonas. Bol. Geoc. da Petrobras, 15(2): 227-251.

CUTRIM A0, RODRIGUES RMM \& MOURA IB. 2004. Avaliação de caminhamentos eletromagnético e elétrico e de SEV na prospecção de água subterrânea no Grupo Cuiabá - MT. In: Congresso Brasileiro de Águas Subterrâneas, XIII, 2004, Cuiabá (MT), ABAS, 8 pp.

DOBRIM MB \& SAVIT CH. 1988. Geophysical Prospecting. 4 ed., McGraw-Hill, Geology Series, New York, 867 pp.

GALLAS JDF. 2000. Principais métodos geoelétricos e suas aplicações em prospecção mineral, hidrogeologia, geologia de engenharia e geologia ambiental. Doctorade thesis, UNESP, Rio Claro, 259 pp.

LOKE MH \& BARKER RD. 1996. Rapid least-squares inversion of apparent resistivity pseudosections by a quasi-Newton method. Geophysical Prospecting, 44: 131-152.

NOGUEIRA ACR \& SARGES RR. 2001. Characterization and genesis of waterfalls of the Presidente Figueiredo region, Northeast State of Amazonas, Brazil. An. Acad. Bras. Ciênc., 73(2): 287-301. ISSN 0001-3765.

ORRELLANA E. 1972. Prospeccion Geoelectrica en Corriente Continua. Ed. Paraninfo, Madrid. $523 \mathrm{pp}$. 
REIS NJ, ALMEIDA ME, RIKER SL \& FERREIRA AL. 2006. Geologia e Recursos Minerais do Estado do Amazonas. Texto explicativo dos mapas geológico e de recursos minerais do Estado do Amazonas, 1/1000000, Convênio CPRM/CIAMA-AM, Manaus (AM), 64 pp.

SILVA CL. 2005. Análise da tectônica cenozóica da região de Manaus e adjacências. Rio Claro (SP), Doctorade thesis, UNESP/Rio Claro, 282 pp. SOUZA MM. 1974. Perfil Geológico da Br-174 (Manaus-Boa Vista) no trecho: Manaus - Serra do Abonari. In: Cong. Bras. Geol., 28., 1974.
Porto Alegre. Anais... Salvador, SBG, V.2, 29-33.

SOUZA VS \& NOGUEIRA ACR. 2009. Seção geológica Manaus - Presidente Figueiredo (AM), borda norte da Bacia do Amazonas: um guia para excursão de campo. Revista Brasileira de Geociências, SBG, 39(1): 16-29.

TELFORDWM, GELDART LP \& SHERIFFRE. 1990. Applied Geophysics. 2nd ed., Cambridge University, Cambridge. 770 pp.

\section{NOTES ABOUT THE AUTHORS}

João da Silva Carvalho. Geologist graduated at Universidade Federal do Amazonas (UFAM), Master's degree in Geophysics at Universidade Federal do Pará (UFPA) and PhD degree in Climate and Environment at Instituto Nacional de Pesquisas da Amazônia / Universidade do Estado do Amazonas (INPA/UEA). Currently is Adjunct Professor at UFAM and develops activities in applied geophysics, with emphasis on the environment.

Javier Tomasella. Researcher at Centro de Ciência do Sistema Terrestre (CCST - INPE). Graduated in Water Resources Engineering at Universidad Nacional del Litoral, Master's degree and PhD degree in Civil Engineering at Instituto de Pesquisas Hidráulicas. Currently is senior technologist at Instituto Nacional de Pesquisas Espaciais. Has experience in the field of Hydrology, working on the following topics: impact of land use changes on the hydrological response of watersheds at different spatial scales, and in the study of extreme hydrological events.

Shozo Shiraiwa. PhD in Geophysics at Universidade de São Paulo, is currently Volunteer Professor at Universidade Federal de Mato Grosso, where acts as advisor on the Graduate Program in Environmental Physics and Water Resources. Develops activities with inductive electromagnetic geophysical methods, GPR, gravimetry, magnetometry and resistivity, applied to hydrogeology, mineral prospecting and soil and water contamination.

Rutenio Luiz Castro de Araujo. Graduate in Physics at Universidade Federal do Rio de Janeiro, MSc degree in Geophysics at Universidade de São Paulo and a PhD degree in Geophysics at Universidade Federal do Pará. Currently is Titular Professor at Universidade Federal do Amazonas and consultant in Applied Geophysics. Has experience in Geosciences with an emphasis on geothermal and thermal flow, working on the following topics: shallow geothermal, environmental geophysics, geothermal flow, resistivity, electrical and correlation radiometry. 